\title{
DIN ÎNSEMNĂRILE PROFESORULUI GHEORGHE CANTACUZINO (1900-1977)
}

I. MEMORES ENVERS LES FORS POLITIQUES ROUMAINS EN CE QUI CONCERNE LE PROBLEME DE LA FORMATION DE LA LANGUE ET DU PEUPLE ROUMAIN.

II. NOTES CONCERNANT LES FOUILLES ARCHEOLOGIQUES DU MONASTERE PUTNA.

Le professeur Georges Cantacuzène, né le 6 mars 1900 et décédé le 21 septembre 1977, esprit combatif et actif s'est impliqué directement dans les actions scientifiques de l'Institut d'Archéologie de Bucarest, prenant des notes pendant divers manifestations scientifiques, faisant des aide-mémoires envers les institutions compétentes de l'état.

Une bonne partie de ces notes se trouvent au Musée National d'Histoire de la Roumanie. Nôtres intentions est de les publier, même partiellement. Pour cela nous commençons avec le problème concernant la formation de la langue et du peuple roumain, ainsi que les fouilles du Monastère Putna.

MOTS CLEFS : Georges Cantacuzène, langue et peuple roumain, Putna.

CUVINTE CHEIE: George Cantacuzino, limba şi poporul român, Putna.

În ultimul an al secolului al XIX-lea, pe 6 martie 1900 , se năştea într-o familie ce a dat ţării voievozi, ctitori de monumente şi oameni de seamă viitorul profesor şi arheolog Gheorghe Cantacuzino. Bunicul său, de la care a preluat prenumele, era bine-cunoscutul Gheorghe Cantacuzino (1832-1913), zis „Nababul”, șef al P artidului Conservator, prim-ministru şi ministru în diverse legislaturi. Tatăl său, Grigore Cantacuzino (1872-1930), va îndeplini la un moment da funcţia de primar al Bucurteştilor, iar mama sa, Alexandrina Cantacuzino, născută Palady (1881-1944), a fost o însufleţită feministă. Soţia profesorului arheolog, Zoe, provenea din neamul Grecenilor.

Încă din adolescenţă se dedică studiului știinţelor umaniste. Studiile liceale le face la urmaşa fostei Academii Domneşti faimosul Liceu „Sf. Sava” din Bucureşti şi la Lausanne, în Elveţia, căpătând solide cunoştinţe în limbile clasice şi moderne.

Primul război mondial îl determină să ia arma în mână în vederea apărării tării, pentru ca după aceea să absolve Facultăţile de Drept, în anul 1921, şi de Litere, secţia istorie şi filologie clasică, în anul 1922, ambele din Bucureşti. Apoi, timp de cinci, între 19231927, se specializează în antichităţile greco- romane, la Facultatea de Litere a Universităţii din Paris, la „Collège de France” şi la „Ecole des Hautes Etudes Historiques", şi în papyrologie greacă, la universităţile din Roma şi Milano.

În toată perioada studiilor va beneficia de îndrumările unor reputaţi profesori participând la numeroase săpături arheologice din România, Franţa, Italia și Africa de Nord. Se socotea, şi cu mândrie o spunea, elev al lui Vasile Pârvan şi Jerome Carcopino.

Teza sa de doctorat, susţinută în anul 1927 la Universitatea din Bucureşti, Facultatea de Litere, intitulată Câteva corpuri barbare din armata romană de la Augustus la Gallienus, obţinând magna cum laudae, va fi publicată în anul 1928.

Între anii 1929-1938 a fost docentconferenţiar cu titlu provizoriu, iar între anii 1938-1948 conferenţiar definitiv la Facultatea de Litere din Bucureşti, catedra „Instituţii şi antichităţi grecești”. După anul 1948, fiind îndepărtat din Universitate, a fost referent ştiinţific, apoi cercetător şi cercetător ştiinţific principal la Muzeul Naţional de Antichităţi, transformat în anul 1956 în Institutul de Arheologie al Academiei Române din Bucureşti, unde va lucra până la sfârşitul vieţii. 
Primele sale lucrări publicate, în mod firesc, tratează probleme de istorie şi arheologie greco-romană —unităţi militare romane, torţi ştampilate de amfore greceşti şi ponduri, inscripţii şi papyri, castrul roman de la Băneasa (jud. Teleorman) sau zidul elenistic de la Histria.

După anul 1952, prin natura împrejurărilor politice, este nevoit a se „reprofila” spre arheologia medievală participând la săpături arheologice din cuprinsul oraşului Bucureşti şi din împrejurimile sale -Ciurel, Mihai Vodă, Movila Gorgani, casa Dudescu de pe strada Apolodor nr. 13, mănăstirea Iezerul de pe cuprinsul actualului sat Căldăraru (comuna Cernica), Mănăstirea Cernica, Palatul brâncovenesc de la Potlogi (jud. Dâmboviţa), mănăstirea Cătălui din comuna Căscioarele (azi jud. Călăraşi), Târgşoru Vechi de lângă Ploieşti.

Dar cum arheologia ascunde numeroase surprize, spre sfârşitul vieţii s-a specializat în studiul arheologiei funerare neolitice pentru a publica mormintele apărute în necropola de la Căldăraru-Cemica.

Pe şantierele sale şi-au făcut ucenicia numeroşi tineri viitori istorici, arheologi, muzeografi şi profesori — cu toţii participând la ,lecţiile" de interpretare a problemelor iscate de descoperiri, la discuţiile ce aveau loc cu numeroşii invitaţi ce veneau să vadă monumentele descoperite. Iar în privinţa colaborării cu diferite instituţii, pentru obţinerea de fonduri în vederea cercetării obiectivelor propuse a apelat la Muzeul de Istorie a Municipiului București, Muzeul de Istorie din Călăraşi, Muzeul de Arheologie din Olteniţa, Direcţia Monumentelor Istorice, Patriarhia Română etc.

În anul 1969, chiar de la creare, a fost ales membru al Academiei de Ştiinţe Sociale şi Politice.

Profesorul Gheorghe Gr. Cantacuzino, „Prinţul” cum i se spunea, a încetat din viată în ziua de 21 septembrie 1977, la echinoxul de toamnă, şi a fost înmormântat în cavoul familiei din Cimitirul Bellu din Capitală.

Fire combativă şi activă s-a implicat direct în acţiunile ştiinţifice ale Institutului de Arheologie din Bucureşti, luând note rezumative la diverse manifestări ştiinţifice, mergând în audienţe şi făcând memorii către instituţile competente ale statului.

O mare parte a acestor însemnări se păstrează în cadrul fondului arhivistic Gheorghe Cantacuzino, ce se află la Muzeul Naţional de Istorie a României. O altă parte, încă necercetată, se află la Arhivele Naţionale din Bucureşti, donate de către familia profesorului după decesul acestuia.

Intenţia noastră, ce i-am fost elev pe şantierele arheologice conduse de Dânsul în perioada anilor 1964-1968, este de a încerca o publicare —el puţin parţială- a lor. Sperăm astfel să facem cunoscut, generatiilor mai tinere, munca şi activitatea înaintaşilor noştri ce s-au dedicat istoriei şi arheologiei româneşti într-o perioadă nu tocmai lipsită de griji şi, uneori, de consecinţe.

\section{MEMORII ADRESATE FORURILOR POLITICE ROMÂNEŞTI ÎN PROBLEMA FORMÃRII LIMBII ŞI POPORULUI ROMÂN}

După cum se știe, în anul 1960 apărea Tratatul de Istorie a României, editat de către Academia R.P.R. Capitolul referitor la formarea limbii şi poporului român era redactat de către academicienii Constantin Daicoviciu, Emil Petrovici şi Gheorghe Ştefan. Iar pregătirile redactării acestui capitol s-au făcut în cadrul Comisiei pentru studierea formării limbii şi poporului român, comisie ce a funcţionat, sub egida Academiei, în perioada 1955-1963.

Desfiinţarea respectivei Comisii, precum şi disputele ştiinţifice, atât interne, cât şi internaţionale, privind formarea limbii şi poporului român au împins cele două „tabere" la a apela la factorul politic —în speţă Partidul Muncitoresc Român, „forţa politică conducătoare" ce aviza cine, ce şi cum să publice lucrările de istorie.

A nu se uita că ,,manualul” lui Mihail Roller (1908-1958, sinucis), din anul 1947 -Istoria României; manual unic pentru clasa a VIII-a secundară- a devenit carte de căpătâi pentru toţi cei ce studiau istoria, punându-se accent pe influenţa predominant slavă în formarea limbii şi poporului român. Iar mai toate lucrările istoricilor antebelici Nicolae Iorga, Gheorghe Brătianu, Constantin C. Giurescu etc. - erau la inuex. 
Până şi Tratatul din anul 1960, cu tot ,naţionalismul" său, făcea abstracţie de opiniile "istoricilor burghezi" insistând pe concepţia marxistă a dezvoltării istorice.

Fapt pozitiv, a perioadei republicane nou instalate, o constituie avântul remarcabil al săpăturilor arheologice. Fondurile sunt aproape nelimitate ... dar publicarea este în mare întârziere, una din cauze fiind şi numele, mai mult sau mai puţin pătat, al celor ce urmau să semneze.

Detaşarea politică de Moscova, din anii de după moartea lui Stalin (1953) şi mai ales de după revoluţia maghiară din anul 1956, de altfel şi ultimii ani de viaţă ai lui Gheorghe Gheorghiu-Dej (1901-1965) au părut a reprezenta o anumită liberalizare ideologică, deşi închisorile — până la decretul din 1964continuă a fì pline de deţinuţi politici.

Se pregătea plenara C.C al P.M.R. din 15-22 aprilie 1964 când s-a adoptat „Declarația cu privire la poziţia Partidului Muncitoresc Român în problemele mișcării comuniste şi muncitoreşti internaționale", o detaşare totală faţă de Moscova, dar nu de ideologia comunistă.

În acest climat politic revelatoare, în parte, sunt memoriile înaintate forurilor politice superioare de către profesorul Gheorghe Cantacuzino, ce ia atitudine în privinţa disputelor ştiinţifice privind formarea limbii şi poporului român, situându-se ferm de partea colegului său, profesorul Ion Nestor (1905-1974).

Profesorul Ion Nestor redactase diverse capitole de preistorie din Tratatul apărut în anul 1960, pusese pe picioare arheologia ştiinţifică medievală românească şi coordona o parte a săpăturilor privind aşa numita perioadă prefeudală, inclusiv pe cea a formării poporului român.

Respectivele memorii şi adrese, din anii 1964-1965, sunt în număr de 11. Dar înainte de a le prezenta a nu se omite faptul că încă nu fuseseră publicate, printre altele, următoarele lucrări:

1. Gheorghe Diaconu, Tîrgşor - necropola din sec. III-IV e.n., Bucureşti, 1965.

2. Bucur Mitrea, Constantin Preda, Necropole din sec. IV e.n. în Muntenia, București, 1966

3. Eugenia Zaharia, Săpăturile de la Dridu, Bucureşti, 1967.

4. Gheorghe Stefan, Ion Barnea, Maria Comșa, Eugen Comşa, Dinogetia. I. Aşezarea feudală timpurie de la Bisericuta-Garvăn, București, 1967.

5. Nicolae Zaharia, Mircea PetrescuDîmboviţa, Emilia Zaharia, Aşezări din Moldova : de la paleolitic până în secolul al XVIII-lea, Bucureşti, 1970.

6. Petre Diaconu, Dumitru Vîlceanu, Păcuiul lui Soare. Cetatea bizantină, vol.I, Bucureşti, 1972.

7. Ligia Bârzu, Continuitatea populatiei autohtone in Transilvania in secolele $I V-V$ (cimitirul nr. 1 de la Bratei), Bucureşti, 1973.

8. Maria Comșa, Cultura materială veche românească (aşezările din secolele VIII-X de la Bucov - Ploieşti), Bucureşti, 1978.

9. Miron Constantinescu, Constantin Daicoviciu, Ştefan Pascu, Compendiu Istoria României, 1969.

10. Andrei Oţetea, Ion Nestor, Ion PopescuPuţuri, Istoria poporului român, București, 1970. 


\section{ANEXE \\ 1. MEMORIU TRANSMIS COMITETULUI CENTRAL AL P.M.R., SECŢIA ŞTIINTT̃ ŞI CULTURĂ, ÎN ZIUA DE 7 FEBRUARIE $1964^{\prime}$}

Cätre:

COMITETUL CENTRAL

- Sectia ştiintă şi cultură -

(În atentia tov. Vasile Dinu)

Considerăm necesar a aduce la cunoştința Seçliei ştiintă şi cultură, o situatie păgubitoare, care constituie o oprelişte serioasă în rezolvarea unor probleme esentiale de interes nafional.

Comisia pentru studiul formării limbii şi poporului român, creată pe lângă Academie R.P.R. la mijlocul anului 1955 şi desfiintată la sfârşitul anului 1963, s-a ocupat şi de cercetări arheologice în legătură cu această problemă. Cercetările au avut ca obiective: culturile materiale formate pe teritoriul R.P.R. în epoca prefeudală începând din sec. III î.e.n. până în sec. XIV în epoca feudală, stabilirea periodizării şi evolufiei acestor culturi, a caracterului şi a legăturilor lor cu populatia bășsinaşă şi cu popoarele imigrate pe teritoriul țării noastre.

La această sarcină s-au consacrat un grup de arheologi, care sub conducerea și îndrumarea prof. I. Nestor și cu fonduri procurate in parte de la Comisia amintită, în parte de la muzeele din provincie și uneori de la Institutul de Arheologie, au efectuat săpături ample în anumite puncte alese cu scopul de a găsi materiale arheologice şi de a dobândi informaf̧ii noi în legătură cu formele culturii materiale și cu populațiile din perioada arătată.

În acest scop au fost executate între 1956 și 1963 în diferite regiuni şi localităti din tară cercetările arheologice următoare:

a. În Transilvania, s-au făcut lucrări în regiunea centrală pe teritoriul comunei Bratei, din $r$. Mediaş, și în regiunea de est pe teritoriul comunelor Sălaşuri, Bezid, Filiaşi, din regiunea Mureș Autonomă Maghiară.

b. În Muntenia, au fost efectuate săpături la Ipotești, r. Slatina, la Cândeşti şi Budureasca, la Bozieni, Vadu Săpat, Bucov, Sărata Monteoru, toate localităti din regiunea Ploieşti, cât și la Dridu, în r. Urziceni, reg. București.

c. In Moldova, au fost îndeplinite vaste cercetări de suprafață şi au fost identificate peste 100 de aşezări din epoca de formare a poporului român (sec. V-XI e.n.)

d. În Dobrogea, au avut loc săpături ample pe teritoriul comunei Basarabi, în aşezarea antică de la Dinogetia (Garvăn) și în ostrovul numit Păcuiul lui Soare.

e. In zona oraşului București. cercetările arheologice s-au făcut în aşezări din epoca prefeudală şi feudală timpurie şi anume in prima etapă (1953-1958) de către şantierul arheologic Bucureşti, iar în etapa a doua (1959-1963) de către Muzeul de Istorie al Oraşului Bucureşti, executându-se săpături în total in 10 puncte.

Astfel, în perioada de la 1956-1963 a avut loc o vastă activitate de cercetäri arheologice desfäsurate pe 12 santiere, care toate s-au ocupat de problemele complexe ale formării poporului român. au cuprins perioada de la sec. III până la sec. XII e.n. si au studiat culturile materiale și populatia băștinașă sau imigrată pe teritoriul tării noastre în acea vreme.

Menfionăm că pentru cercetările amintite, Comisia pentru studiul formării limbii şi poporului român, muzeele provinciale şi in unele cazuri chiar Institutul de Arheologie (pentru şantierele de la Basarabi şi Păcuiul lui Soare) au cheltuit până acum sume considerabile pentru plata bratelor de muncă sau a personalului știintific și pentru procurarea uneltelor și accesoriilor de lucru.

Tinând seama de cele arătate mai sus, reiese că se impune de urgentă valorificare și publicarea rezultatelor obtinute prin săpăturile santierelor mentionate.

Examinând din acest punct de vedere situatia reală în care se află acum cercetările arheologice ale șantierelor, care se ocupă de problemele formării poporului român, se pot face următoarele constatări:

\footnotetext{
'Se prezintă principalele rezultate ale cercetării arheologice din ultimii ani. se susţine publicarea cât mai grabnică a acestora.
} 
1. Colectivele unor şantiere nu numai că au terminat pe teren săpăturile, dar încă au prelucrat, au valorificat în întregime materialele descoperite şi au redactat, după necesităti, câte un studiu amplu sau câte un studiu cu caracter monografic, care a fost dactilografiat, definitivat și este pregătit pentru tipar.

Aceasta este situaţia pentru săpăturile efectuate în următoarele localităti, anume :

a. Cercetările arheologice privind aşezarea din sec. V-VI e.n. de la Ipoteşti fac obiectul unui studiu definitiv redactat, dactilografiat având 54 pagini, întocmit de Marin Popescu şi Victor Teodorescu.

b. Cercetările referitoare la aşezările din sec. VI-VII e.n. situate pe teritoriul comunelor Cândeşti, Budureasca, Bozieni, Vadu Săpat au fost pe deplin valorificate într-un studiu amplu având 140 pagini dactilografiate, intocmit de Victor Teodorescu, colaborator al Muzeului din Ploieşti.

c. Cercetările arheologice efectuate de Szekely Zoltan privind aşezările romano-slave, din sec. VIVII e.n., aflate pe teritoriile unor localităti din Transilvania de est au fost valorificate de el intr-un studiu definitiv având 80 pagini dactilografiate, care aşteaptă tiparul.

d. Rezultatele săpăturilor efectuate pe teritoriul oraşului Bucureşti sau în apropiere in suburbanele Militari, Străulești, Cătelul Nou, Fundeni privesc diverse aşezări încadrate cronologic între sec. III şi sec. X e.n. şi fac obiectul unor studii având circa 100-150 pagini dactilografiate, redactate de Margareta Constantiniu, Gh. Cazimir şi P. Panait.

Se constată prin urmare că rezultatele arheologice şi concluziile știintifice ale cercetărilor mentionate la punctele $\boldsymbol{a}, \boldsymbol{b}, \boldsymbol{c}, \boldsymbol{d}$ au fost consemnate în lucrări definitive pregătite pentru tipar totalizând circa 450 pagini dactilografiate de text, osebit note si ilustratii. Acestea constituie materialul unui volum. foarte pretios pentru problemele formării poporului român, deoarece studiază culturile materiale din sec. V-VII e.n. pentru care avem până acum foarte putine date.

Pe baza materialelor descoperite, autorii au arătat caracteristicile culturilor materiale din această vreme si persistenta elementelor de cultură romană și dacică în cadrul culturii din Transilvania de est si din Muntenia de vest sau de centru.

e. Pentru cercetările arheologice privind aşezarea din sec. $X-X I$ e.n. pe teritoriul comunei Dridu, $r$. Urziceni, rezultatele știinfifice au fost consemnate intr-o monografie definitivată, redactată de Eugenia Zaharia, cuprinzând 400 pagini dactilografiate care pot forma un alt volum. Această lucrare, care a fost inaintată Editurii Academiei, fiind trecută în planul ei pe 1964, studiază formarea si dezvoltarea culturii Dridu din elementele culturii provinciale romane si este deci foarte importantă pentru concluziile istorice ce se deduc si pentru cunoasterea culturii materiale a populatiei locuind în acea vreme în Muntenia de est.

$f$. Cercetările de suprafată efectuate în diferite regiuni din Moldova au permis redactarea unei ample lucrări, definitive, având 650 pagini dactilografiate redactate de prof. Mircea Petrescu-Dâmbovifa in colaborare cu Nicolae şi Emilia Zaharia, lucrare care se referă la foarte numeroase aşezări din sec. $V-X$ e.n. şi aduce informatii noi în legătură cu problemele formării poporului român. Această lucrare poate constitui un alt volum editorial.

Din cele arătate se constată clar că pe baza studierii cercetărilor arheologice efectuate în ultimii ani si indicate la punctele a-fau fost redactate lucrări ample de valorificare ale rezultatelor obtinute si că aceste lucrări sunt terminate, putând forma trei volume editoriale.

Editarea imediată a rezultatelor arheologice si a concluziilor istorice dobândite prin săpăturile acestor santiere este un imperativ national.

2. Sunt alte şantiere ale căror cercetări de teren sunt pe sfârșite, iar valorificarea materialelor este destul de înaintată, precum sunt: Cercetările executate de S. Morintz în așezarea din sec. VII e.n. pe dealul Ciurel (teritoriul oraşului Bucureşti), acele ale prof. Ion Barnea în aşezământul feudal din sec. $X$ e.n. de la Basarabi şi lucrările lui Ligia Bârzu referitoare la cimitirul din sec. IV-V e.n. de la Bratei. Redactarea şi pregătirea definitivă a textului şi a ilustratiilor pentru tipar ar putea fi terminate pentru aceste şantiere în cursul anului 1965, aceste studii ample pot forma două alte volume pentru tipar.

3. A treia categorie de șantiere sunt într-o situafie deosebită. Unele, precum sunt cercetările din aşezările de la Bratei datând din sec. V-VII e.n., acele privind aşezările din sec. X-XII e.n. de la Bucov şi lucrările referitoare la cetatea din ostrovul Păcuiul lui Soare, nu sunt încă terminate pe teren; altele au lucrările de valorificare și de redactare în curs şi încă nedefinitivate, cum e cazul pentru cimitirul de incineratie din sec. VI-VII e.n. de la Sărata Monteoru, care cuprinde, pe lângă elemente slave, numeroase elemente culturale de tradifie romanică, atestând prezenţa unei populatii băştinaşe care convietuia cu triburile slave.

Lucrările acestei categorii de şantiere urmează să fie publicate după desăvârşirea lor.

Din expunerea prezentată se constată că în stadiul actual al lucrărilor efectuate în ultimii şapte ani în legătură cu problemele formării poporului român, au fost pregătite si definitivate, sub îndrumarea dată de prof. I. Nestor, o serie de lucrări, care aduc la cunosstintă rezultate și concluzii noi arheologice si istorice. Pentru rezolvarea acestor probleme, lucrările amintite au o însemnătate uriașă incât se impune 
editarea lor imediată deoarece aceste studii vor clarifica pe baza noilor materiale descoperite o serie de chestiuni şi de aspecte total necunoscute sau cunoscute imperfect şi privite printr-o interpretare eronată.

Este de neconceput ca publicarea acestor lucrări, care aduc o contributie covârsitoare în problemele de interes national, să fie lăsată în părăsire sau să fie tergiversată. Intr-adevăr, aceste lucrări dovedesc continuitatea unor forme importante ale culturii materiale atestând prezenta populatiei băstinașe la nord de Dunăre de la sec. IV până la sec. XI-XII e.n.

Chiar dacă ipotetic am presupune că unele din aceste lucrări ar confine omisiuni sau ar cuprinde interpretări care ar putea apărea acum oarecum hazardate, dar care pot fi confirmate in viitor, se impune neapărat editarea lor căci lucrările reprezintă un mare pas înainte fată de ceea ce se cunostea până acum, iar progresul stiintific se realizează numai prin dibuire, stăruire și salturi.

Având în vedere expunerea de mai sus, considerăm că este necesar de a se lua de indată următoarele măsuri :

I. De a se edita de urgență lucrările definitivate arătate la paragraful 1, punctele a-f.

II. De a se lua măsuri pentru a se grăbi definitivarea lucrărilor indicate la paragraful 2.

III. De a se asigura mijloacele materiale corespunzătoare pentru continuarea cercetărilor arheologice arătate la paragraful 3.

IV. În legătură cu cercetarea arheologică a problemelor formării poporului român este neapărat necesar de a se crea un colectiv de coordonare pe lângă Academie sau pe lângă Institutul de Arheologie, care să îndrume în continuare cercetările viitoare sau valorificarea materialelor incă nestudiate apartinând şantierelor mentionate şi să se procedeze la operafiunile necesare editării lucrărilor terminate privind problemele formării poporului român.

Crearea acestui colectiv de coordonare se impune negresit, după desfiintarea Comisiei anterioare pentru studiul formării limbii și poporului român si mai ales dacă se are în vedere că săpăturile în curs pentru aceste probleme se fac cu fonduri procurate de muzeele provinciale si cu colaborarea personalului lor, care trebuie prin urmare supravegheat si îndrumat.

\section{LUPTĂM PENTRU PACE}

(7) februarie 1964

Prof. Gh. Cantacuzino

Colaborator ştiintific al Institutului de Arheologie

\section{SUPLIMENT LA MEMORIU CU ALTE DATE IMPORTANTE ${ }^{2}$}

Pe lângă informatiile cuprinse în memoriu, consider necesar a atrage atentia asupra unor lucrări deosebit de importante, care au fost efectuate sau care trebuie efectuate si aduc o contributie esentială la problema continuitătii populatiei băstinașe in regiunile de la nordul Dunării și anume:

A. Amintim că cercetătorul Gh. Diaconu a finut la 25 ianuarie 1964 la Institutul de Arheologie interesanta comunicare intitulată ,Prezenţa geto-dacilor în cultura Cerneahov pe baza săpăturilor de la Târgșor", comunicare în care a dovedit că în necropola din sec. IV e.n. de la Târgşor există pe lângă mormintele altor populafii, morminte geto-dace de incinerafie, care contin un bogat inventar de vase de factură dacică sau de factură provincială romană. Aceste descoperiri dovedesc în mod cert prezenta populatiei băstinasse dacice din regiunea Târgssor în sec. IV e.n. în timpul ocupatiei gotice. Studiul menfionat, care va fi publicat în una din revistele Institutului de Arheologie, constituie un pas înainte în cercetarea formării poporului român.

B. Mentionăm de asemeni însemnata contribuţie adusă prin comunicarea finută la 12 febr. 1964 de Margareta Constantiniu şi P(anait) Panait, arătând rezultatele cercetărilor arheologice din 19621963 în aşezările din sec. X e.n. situate în suburbanele Băneasa și Străuleșii de pe teritoriul Bucureştilor. Aceste cercetări au dovedit o cultură materială cu continut romano-bizantin având legături apropiate cu Imperiul Bizantin și asemănări mari cu cultura Dridu, ceea ce confirmă concluziile formulate în monografia săpăturilor executate în ultimii ani la Dridu.

\footnotetext{
${ }^{2}$ Supliment la memoniul anterior, din 7 februarie 1964, în care se prezintă ultimele comunicări știinţifice tinute la Institutul de Arheologie din București. Necesitatea redactăni și publicării unor studii referitoare la ceramica geto-dacică şi romanăa.
} 
C. Prin săpăturile şantierului Cernica, pe care l-am condus, s-au descoperit în 1963 două bordeie prefeudale, care după caracteristica găsită datează de la sfârşitul sec. V sau începutul sec. VII e.n. Ceramica găsită într-unul din bordeie este de factură dacică și romană fiind lucrată la roată și atestă prezenta populatiei băstinașe în acest loc înainte de venirea și assezarea triburilor slave. Descoperirile de la santierul Cernica aduc deci o contributie nouă la problema continuitătii populatiei autohtone la nord de Dunăre.

D. O problemă esențială a cărei rezolvare trebuie grăbită este redactarea și editarea unui studiu stiintific amplu cuprinzând ceramica daco-getică de toate categoriile, cu formele și ornamentele ei, care au existat pe teritoriul Daciei. O asemenea lucrare este în curs de întocmire de către cercetătorul (I.H.) Crişan, de la filiala Academiei R.P.R. din Cluj, însă este necesar ca redactarea ei să fie urgentată și editarea ei să fie asigurată, deoarece astfel se vor cunoaste formele ceramicii dacice care au persistat în cursul epocii prefeudale.

E. $O$ problemă știintifică necercetată încă, dar de mare actualitate este pregătirea unui studiu amplu, adâncit privind ceramica romană de la introducerea ei până la încetarea aparitiei ei în Dacia. Acest studiu are o covârsitoare însemnătate, deoarece formele şi decorul ceramicii provinciale romane din sec. I-III e.n. au fost imprumutate si reproduse în epoca prefeudală de ceramica dacică și de ceramica romană de imitatie lucrată de populatia băstinas̆ă. De aceea se impune intocmirea şi publicarea unui studiu temeinic referitor la ceramica romană din Dacia după modelul lucrărilor redactate pentru vasele romane din Pannonia, de către cercetătorii maghiari şi editate în colectia Dissertationes Pannonicae, seria II, Budapesta, nr. 3, 1935 şi $n r .3,1938$.

Deoarece lucrările mentionate aduc o mare contributie la rezolvarea problemelor formării poporului român, credem că este necesar de a se sprijini definitivarea si publicarea lor.

Consider necesar a vă aduce la cunoștintă următoarele:

In ziua de 5 februarie 1964 a avut loc la Sectia de știintă şi cultură audiența în care au fost discutate probleme timp de o oră şi jumătate. Erau prezenti atât conducătorul sectiei cât şi noul său adjunct pe care l-am cunoscut pentru prima oară. În cadrul discutiei au fost atinse următoarele probleme:

1. Modul în care a functionat în ultimii ani Comisia pentru studiul problemelor formării limbii şi poporului român, creată în 1955 pe lângă Academia R.P.R.

2. Cercetările arheologice efectuate privind aceste probleme cu fonduri procurate de comisia menţionată şi de alte institufii.

3. Rezultatele obtinute prin aceste cercetări şi situafia actuală a valorificării lor.

4. Opreliştile, care au existat şi mai există, în calea editării rezultatelor qcestor cercetări arheologice.

5. Măsurile de îndreptare ce se impun.

Dupà o discufie destul de amplă a acestor chestiuni, mi s-a cerut întocmirea şi prezentarea de urgentã a unui memoriu. Am redactat în grabă acest memoriu şi am fost din nou primit în audientă in ziua de 7 februarie 1964, când am remis acest act după care vă trimit o copie, rugându-vă însă a nu arăta nici de a vorbi altora despre acest act.

In cadrul audientei de la 7 februarie 1964, au fost discutate din nou in lumina memoriului adus toate problemele în legătură cu cercetarea formării poporului român.

Vă aduc la cunoştință rezumativ aspectele cele mai importante ale acestei discufii şi anume:

a. In privinţa modului de funcţionare și a activităţii comisiei pentru studiul formării limbii poporului român în ultimii ani impresiunea avută este defavorabilă.

b. Forurile superioare, deşi aveau în cunoştintă că în atributiunile acestei comisii intrau şi cercetări arheologice privind epoca de formare a poporului român (perioada de la sec. III e.n. la sec. XIII e.n.) nu cunoșteau însă de loc rezultatele cercetărilor efectuate si în majoritatea cazurilor nu stiau nici de executarea săpăturilor în anumite localităti. 
c. $\mathrm{Nu}$ se cunostea de loc de către forurile superioare stadiul în care valorificarea materialelor arheologice si a rezultatelor obtinute de santierele care s-au ocupat de problemele formării poporului român. Persoanele prezente la discufii au fost foarte mirate și impresionate plăcut când le-am comunicat situatia înaintată de valorificare a unor lucrări redactate de aceste șantiere.

d. In privinta culturii Dridu şi a continutului ei în mare parte romanic, am observat o şovăire, pe care m-am străduit să o înlătur cu diferite argumente.

e. Cred că forurile superioare au fost convinse de necesitatea editării urgente a tuturor lucrărilor deja pregătite cât si a acelora în pregătire privind aceste probleme.

f. Din cele discutate şi amintite, am părerea că memoriul, pe care l-am trimis, va avea un efect salutar și va grăbi luarea unor măsuri corespunzătoare pentru a înlesni executarea și valorificarea cercetărilor privind problemele formării poporului român.

g. Am pus de asemeni in discutie crearea la Institutul de Arheologie sau la Academie a unui colectiv sub conducerea Dvs. care să continue efectuarea cercetărilor arheologice pe teren, să desăvârşească valorificarea lor şi să le asigure editarea.

h. Tinând seama de însemnătatea acestor probleme, cred că este neapărat necesar ca după innapoierea dvs. în București, să vă ducefi la Sectia ştiință şi cultură: de o parte pentru a prezenta lucrările definitive care urmează să fie publicate și pentru a stabili cu care fonduri, prin care editură şi în ce conditii trebuie editate şi de altă parte pentru a preciza problema infiinfării unui colectiv condus de Dvs. pentru cercetările arheologice în curs şi viitoare referitoare la problemele formării poporului român.

Din investigatiile făcute de mine au reieșit clar urmätoarele constatäri:

I. Forurile superioare nu au fost informate în mod just cu privire la săpăturile efectuate, la rezultatele dobândite sau la valorificarea monumentelor şi materialelor descoperite de către grupul de arheologi, care au lucrat sub îndrumarea dvs. şi cu diverse fonduri în problemele formării poporului român.

II. Forurile superioare manifestă încă înfelegere şi bună voinfă pentru o rezolvare eficientă şi rapidă a greutătililor actuale.

III. Lipsa totală de informare precisă a organelor superioare a constituit una din cauzele esentiale care au creat situatia actuală.

$I V$. pentru activitatea viitoare este absolut necesar de a se înlătura această gravă omisiune și de a se întreprinde o actiune sustinută de incunoștintare și de evidentiere a muncii arheologice depuse pe teren, a rezultatelor obtinute si a studiului lor de valorificare.

În urma concediului ce ati luat, sperăm că veti reveni la Bucureşti cu puteri sporite pentru a da lupta spre o solutionare justă a acestor probleme.

Vă trimit salutările mele cordiale 


\section{MEMORIU ADRESAT LA 21 MARTIE 1964 COMITETULUI CENTRAL AL P.M.R. REFERITOR LA NECESITATEA UNOR AMPLE CERCETĂRI ARHEOLOGICE PRIVIND PERIOADA CONSTITUIRII STATELOR FEUDALE ROMÂNEŞTI, SEC. X-XV.}

\section{Către:}

\section{COMITETUL CENTRAL AL P.M.R.}

- Sectia știintă și cultură -

(În atenţia tov. Vasile Dinu și Ilie Diculescu)

In completarea datelor continute în raportul nostru principal, credem necesar de a aduce la cunoștință unele informații suplimentare cu privire la orientarea cercetărilor arheologice referitoare la problemele formării poporului român.

În cadrul Comisiei privind studiul formării limbii şi poporului român, care a funcţionat pe lângă Academia R.P.R. de la 1957 până la 1963, când a fost desfiinţată, au fost executate importante cercetări arheologice, mentionate in memoriul nostru anterior, care toate au fost efectuate in anumite locuri la suprafata cărora s-au găsit printr-o prospectie prealabilă urme arheologice atestând o locuire de durată variabilă. Cele mai multe din locurile, care au fost astfel săpate, nu au nici o pomenire într-un izvor scris. Astfel, cercetările au fost făcute intre 1957 şi 1963 după indicii pur arheologice în numeroase aşezări situate în Transilvania, Moldova şi Tara Românească, obținându-se rezultatele deja arătate.

Prin aceste cercetări s-au dobândit însemnate cunoştinfe noi cu privire la cultura materială și la populatia care a locuit în tinuturile de la nord de Dunăre şi pe podişul Transilvaniei între secolele III-X e.n. Ca urmare s-au putut preciza aspectele culturii materiale din sec. X e.n. și legăturile acestei culturi. denumite Dridu, cu populatia proto-română (străromână).

Au mai rămas însă necercetate sau insuficient cercetate anumite situatiuni și probleme de mare însemnătate ce se încadrează cronologic între sec. $X$ şi XV e.n. Această perioadă are o covârșitoare însemnătate în istoria tării noastre, deoarece atunci s-a ajuns la desăvârșirea etnogenezei poporului român.

Într-adevăr în această perioadă s-au produs următoarele procese istorice:

- Desăvârşirea românizării elementelor slave şi turcomane venite pe teritoriul fării noastre.

- Cristalizarea limbii şi poporului român de la forma proto-română (străromână) la aceia definitivă. IXe.n.

- Înjghebarea şi dezvoltarea primelor formaţii statale româneşti, începute în Ardeal încă din sec.

- Formarea şi dezvoltarea unor cetăți, târguri, care ulterior vor crește în importanță și vor dobândi structura de oraş.

- Aparitia şi extinderea relatiilor feudale de productie.

Ori, aceste probleme esentiale din istoria poporului român și care se încadrează cronologic de la sfârșitul epocii prefeudale până la sfârșitul perioadei feudalismului timpuriu, nu au fost cercetate pe plan arheologic in ultimii sapte ani (1957-1963).

Tinând seama de aceste constatări, considerăm că, pe lângă cercetările arheologice orientate spre studiul culturii materiale si populatiei, care au existat pe teritoriul tării noastre intre sec. III si sec. $X$ e.n., este neapărat necesar să se dea și o orientare a cercetărilor spre studiul problemelor privind etapa desăvârsirii formării poporului român între sec. $X$ si sec. XV e.n.

În acest scop se cuvine ca orientarea cercetărilor arheologice referitoare la această vreme să pornească de la informatiile istorice procurate de izvoarele scrise. In lumina cercetării acestor izvoare este util a se efectua sondaje si săpături in zona de constituire a vechilor formatii statale românessti de la sud și de la nord de Carpati si în prim rând in principalele lor centre, precum au fost Câmpulungul, Curtea de Argeș, Târgovişte în Muntenia, apoi cetătile voievozilor Gelu, Glad și Menumorut în Transilvania, apoi vechile centre Siretul, Baia şi Piatra Neamt în Moldova, și desigur încă alte aşezări sau puncta întărite pentru care se pot găsi știri sau urme de cultură materială din epoca feudalismului timpuriu.

Cercetarea prin săpături sistematice a celor mai vechi centre de viată statală a poporului român se impune din toate punctele de vedere: arheologic, istoric, linguistic, social-economic deoarece este cert că unele din aceste vechi centre au ajuns la stadiul de orase si de resedinte domnești, după ce au trecut printr-o lungà evolutie de la așezarea sătească la târg si de la târg la oraș. 
Stabilirea prin lucrări arheologice a etapelor acestei lungi evolutii va umple cel putin în parte intervalul acum gol de stiri istorice privind viata populatiei din Tara Românească si din Moldova intre sec. $X$ si XIV e.n., va aduce informatii noi si esentiale chiar pentru populatia din Transilvania si va procura in orice caz stiri de mare valoare referitoare la organizatia social-economică din acea vreme în toate tinuturile României.

Credem că este necesar a se avea în vedere aceste consideratii cu prilejul organizării cercetărilor arheologice pe o bază nouă, în urma desfiintării în 1963 a Comisiei pentru studiul formării limbii și poporului român şi anume a se avea în vedere:

1. Orientarea cercetărilor arheologice nu numai spre studiul culturii materiale și a populafiei din sec. IV-X e.n., dar incă şi spre studiul formelor de cultură şi populatiei, care a existat între sec. $X$ şi XV e.n. pe teritoriul României.

2. Prevederea mijloacelor materiale pentru a se executa in bune condifii aceste cercetări.

3. Organizarea unui colectiv care să continue cercetările arheologice deja incepute pentru perioada de la sec. IV la sec. X e.n., să initieze pe acele privind perioada dintre sec. Xşi sec. XV e.n. şi să desăvârşească valorificarea şi publicarea rezultatelor deja obținute prin săpăturile efectuate.

LUPT $\breve{A M}$ PENTRU PACE

5. MEMORIU SUPLIMENTAR, ADRESAT ÎN MARTIE 1964, REFERITOR LA PUBLICATII MAGHIARE CE PREZINTĂ IMIGRAREA ROMÂNILOR ÎN TRANSILVANIA, VENIND DIN SUDUL DUNĂRII LA SFÂRŞITUL SEC. XIV, DUPĂ STABILIREA SLAVILOR, UNGURILOR ŞI SAȘILOR.

In completarea datelor cuprinse în memoriul principal cu anexe, depus anterior, considerăm necesar a atrage în special atentia asupra faptului că în ultimii trei ani (1960-1963) au fost publicate la Budapesta sub îngrijirea Academiei Maghiare două studii redactate de cercetătorul ungur György Györffy, care privesc populafiile din Statul ungar de la întemeierea sa până în sec. XIV e.n. Aceste lucrări redactate de acest cercetător, cunoscut prin studii privind populatiile migratoare din sud-estul Europei în Evul Mediu, au o deosebită însemnătate pentru Români, deoarece se ocupă de provenienta și de numărul Românilor în Transilvania, în acea vreme.

Având în vedere importanţa problemelor discutate în aceste lucrări, am considerat oportun a reproduce în alăturata anexa $\mathrm{nr}$. 1, traducerea exactă din limba germană în limba română a paginilor privind pe Românii din Transilvania, astfel cum au fost prezentati de acest autor în studiul scris în limba germană, intitulat: "Numărul populatiei şi desimea ei în Ungaria până în sec. XIV e.n. " editat în volumul Etudes Historiques, I, 1960, Budapest, sub îngrijirea Academiei Maghiare.

Transilvania:

Din citirea paginilor arătate se constată că autorul lor afirmă următoarele despre Românii din

1. Românii popor de păstori, au venit la sfârşitul sec. XII e.n. din Peninsula Balcanică în Transilvania, care era locuită de Slavi, de Maghiari și de Sași.

2. Venirea Românilor în Transilvania a avut loc după mijlocul sec. XII e.n. deoarece şi-au însuşit în sudul Transilvaniei denumirile de sate de la saşi şi în alte părţi ale Transilvaniei denumirile de la Slavi.

3. Imigratia în masă a Românilor a avut loc pe teritoriul Transilvaniei venind din regatul Aşăneștilor, unde în acea vreme au dispărut. lactate.

4. Înmulțirea rapidă a populaţiei româneşti se datorează alimentatiei păstoreşti cu produse

5. În momentul năvălirii Tătarilor în 1240 e.n. numărul total al Românilor din Transilvania atingea aproximativ acel al Secuilor, pe care autorul l-a calculat la 20.000 suflete.

6. Populatia totală a Statului Maghiar în sec. XIII e.n. a fost stabilită după calcule de autor la 600.000 suflete. 
Autorul a ajuns astfel la concluzii cu totul eronate că Românii sunt în cuprinsul Transilvaniei o populatie imigrată din Balcani, adică din statul Asănesstilor la sfârșitul sec. XII e.n., după ce Slavii, Ungurii si Sasii erau deja assezati aci si că numărul lor a fost foarte mic, atingând abia pe cel al Secuilor, adică circa 20.000 persoane, ceea ce reprezenta circa 1/30 din populatia totală a Ungariei în sec. XIII e.n.

Concluziile greşite la care au ajuns unii cercetători maghiari în privinta provenientei şi răspândirii Românilor trebuie să atragă în mod special atentia noastră, cu atât mai mult cu cât ele sunt propagate in limbi străine de mare circulatie, fiind editate în publicafii ale Academiei Maghiare.

Considerăm că aceste concluzii eronate ale unor cercetători maghiari pot fi combătute si înlăturate cu mare succes pe calea cercetărilor arheologice.

De aceea credem că este urgent a se lua următoarele măsuri.

1. Valorificarea şi editarea grabnică a rezultatelor obtinute prin cercetările arheologice efectuate în ultimii 7 ani în diferite locuri din Transilvania şi în alte regiuni ale fării noastre.

2. Organizarea unui colectiv format din cercetători care au mai lucrat, sub conducerea prof. I. Nestor, şi care să continue lucrările arheologice incepute sau în perspectivă în problemele esentiale privind formarea Poporului Român, acordându-se în acest scop mijloacele materiale corespunzătoare.

LUPTĂM PENTRU PACE

\section{ANEXA LA MEMORILLE ANTERIOARE PREZENTÂND REZULTATELE UNOR} IMPORTANTE SĂPĀTURI ARHEOLOGICE PRIVIND SEC. V-VI ȘI X-XII.

\section{$\underline{A N E X A}$}

Săpăturile de la Ipotessti, raion Slatina. Privesc o aşezare din sec. V-VI e.n., săpăturile au fost executate cu sume date de Muzeul Slatina şi Comisia pentru studiul formării poporului român. Materialele arheologice sunt aduse la Institutul de Arheologie și câteva au mai rămas la Muzeul din Slatina. A fost redactat de către Marin Popescu şi Victor Teodorescu un studiu de circa 50 pagini dactilografiate.

Săpăturile de la Cândești şi din alte localităti: Budureasca, Bozieni, Vadu Săpat, toate din regiunea Ploieşti, privesc aşezări din sec. VI-VII. Cercetările au fost executate cu fonduri date de Muzeul Regional Ploieşti şi de Comisia pentru studiul formării poporului român. Materialele arheologice sunt la Muzeul din Ploiești şi la Institutul de Arheologie. A fost întocmit un studiu având circa 140 pagini dactilografiate de către Victor Teodorescu.

Săpăturile de la Bucov, reg. Ploiești. Au fost executate de Maria Comşa cu fonduri date de Institutul de Arheologie şi privesc două aşezări: una din sec. X e.n. şi alta din sec. XII e.n. Materialele arheologice sunt la Institutul de Arheologie. Săpăturile sunt încă în curs de efectuare.

Săpăturile de la Sărata Monteoru, r. Buzău, reg. Ploiești. Privesc cimitirul de incinerafie din sec. VI-VII e.n. Au fost executate cu fonduri date de Institutul de Arheologie. Materialele au fost aduse la acest Institut.

Valorificarea rezultatelor acestor săpături şi a materialelor descoperite este în curs şi unele capitole au fost deja redactate.

Săpăturile de pe teritoriul comunei Dridu, r. Urziceni, reg. București. Au fost executate cu fonduri date de Comisia pentru studiul formării poporului român şi de Institutul de Arheologie. Materialele au fost aduse la acest Institut. Au fost publicate deja rapoartele preliminare ale săpăturilor efectuate aci în anii 1956-1959. Osebit a fost redactată și definitivată o lucrare monografică despre aceste săpături, intocmită de Eugenia Zaharia, lucrarea are circa 400 pagini dactilografiate şi a fost predată Editurii Academiei încă din 1962.

Cercetările arheologice de suprafată efectuate pe teritoriul Moldovei de către Mircea PetrescuDâmboviţa şi Nicolae și Emilia Zaharia. Ca urmare au fost identificate numeroase aşezări din perioada de formare a poporului român şi s-a redactat un studiu definitiv având 650 pagini dactilografiate pregătite pentru tipar. 
Cercetările arheologice executate în assezări din sec. VI-VII e.n. în regiunea de sud-est a Transilvaniei cu fonduri date de Muzeul din Sf. Gheorghe si din Cristurul Secuiesc cât si de Comisia pentru studiul formării poporului român.

Au fost găsite materiale arheologice româno-slave, care se păstrează în muzeele mai sus arătate. Aceste săpături s-au efectuat pe teritoriile comunelor Săiaşuri, Bezid şi Filiaşi. Rezultatele arheologice obtinute au fost valorificate într-un studiu având 80 pagini dactilografiate, pregătite pentru tipar, redactate de către Szekely Zoltan.

Cercetările arheologice de pe teritoriul comunei Basarabi, Dobrogea executate cu fonduri date de Muzeul Constanta, Direcția Monumentelor Istorice şi Comisia pentru studiul formării poporului român. Materialele se află la Institutul de Arheologie.

Rezultatele arheologice obtinute au făcut obiectul unei comunicări şi rapoarte preliminare. Este in pregătire acum un studiu amplu care valorifică rezultatele şi materialele găsite şi care se întocmeşte de către prof. Ion Barnea. Această lucrare priveşte aşezământul monahal şi biserica descoperite sub dealul de cretă, datând din sec X e.n., de la Basarabi.

Cercetările arheologice de la Păcuiul lui Soare, privind o cetate bizantină din sec. X-XII e.n. nu sunt terminate, ci în curs de efectuare. Materialele se află la Institutul de Arheologie.

Cercetările de la Bratei, r. Medias, reg. Brașov, privind un cimitir şi o aşezare din sec. IV-V $s i$ aşezări din sec. V-VII e.n. au fost executate cu fondurile Comisiei pentru formarea poporului român, iar materialele au fost aduse la Institutul de Arheologie. Aceste lucrări sunt încă în curs de efectuare, dar valorificarea lucrărilor din cimitir pentru publicare poate fi terminată în anul 1965.

\section{SCRISOARE A PROFESORULUI GHEORGHE CANTACUZINO CĂTRE PROFESORUL ION NESTOR, DIN 20 MARTIE 1964, REFERITOARE LA AUDIENŢELE LA CARE A PARTICIPAT.}

\section{Tov. PROF. I. Nestor,}

In legăturile cu convorbirile, pe care le-am avut la 18 martie 1964 şi de care aveti cunoştinţă. consider necesar să amintesc părerile exprimate și problemele discutate şi anume:

1. Memoriul anterior, depus de mine, a fost citit şi se află în prelucrare, punctele de vedere cuprinse in acel memoriu au fost acceptate.

2. Raportul trimis de curând de prof. I. Nestor a trecut printr-o primă lectură sii se examinează acum de persoane mai inalte.

3. Intr-un memoriu suplimentar, depus la 18 martie a.c., am atras atentia asupra trei lucrări importante, redactate de cercetătorul maghiar György Györffy in anii 1960-1963, din care una în limba germană, prin care sustine teze cu totul false privind venirea Românilor de la sud de Dunăre in Transilvania la sfârșitul sec. XII e.n. și privind numărul populatiei românești.

4. Discutând modul de a combate aceste afirmatii, cuprinse în lucrările maghiare, am susţinut că solutia justă, nu este de a face polemică, ci de a descoperi materiale noi, a le interpreta si a le discuta de urgentă. Aceasta e singura metodă eficientă si stïintifică, punct de vedere cu care au fost cu totul de acord convorbitori mei.

5. In consecință, este absolut necesar ca cercetările arheologice privind problemele formării poporului român să fie stimulate, organizate pe o bază nouă si înzestrate cu o finantare specială. Cu această solutie, convorbitorii mei au fost de asemeni cu totul de acord însă au amintit că pentru campania din 1964, bugetul fiind deja aprobat si in aplicare, nu se vor putea obtine fonduri noi sau se vor obfine eventual numai mici sume suplimentare.

Această problemă urmează să fie rezolvată în cursul anului 1964, pentru ca organizarea pe baze noi a cercetärilor arheologice privind problemele formärii poporului român să functioneze în 1965.

6. A fost discutat un nou aspect al acestor probleme și anume: absenła unor cercetări privind perioada feudalismului timpuriu, adicà referitoare la perioada de la sec. X la sec. XIV. Am constatat că forurile superioare şi-au format deja părerea că este neapărat necesar să se initieze cercetări privind această perioadă si anume în zonele celor mai vechi formatii statale românești, în centrele și în așezările lor.

7. A fost discutată şi problema reorganizării pe noi baze a cercetărilor arheologice p.: $d$ problemele formării poporului român. Din discutii au reieşit că arheologii clujeni cer înfiintarea unui colectiv format din Ardeleni, care să aibă ca obiective exclusiv cercetările din Transilvania si din Banat. 
Forurile superioare nu sunt însă de această părere, ci înclină mai degrabă către solutia creierii unui colectiv unic având sediul în București.

În sprijinul acestei solutii am dat următoarele argumente:

a. avantajele unei conduceri unice.

b. metodă uniformă de cercetare.

c. o tematică creată pentru întreaga ţară cuprinzând obiective arheologice precise.

d. centralizarea cercetărilor arheologice într-un singur colectiv va permite o utilizare mai judicioasă a fortelor arheologice din tară, inclusiv a celor din Transilvania.

e. repartizarea către un colectiv unic a mijloacelor financiare va impiedica risipa şi cheltuieli nesocotite.

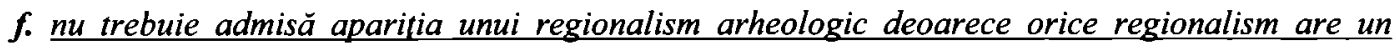
orizont îngust pe când știinta nu are hotare ssi cere orizonturi deschise, cât mai largi.

8. Organizarea unui singur colectiv arheologic cu sediul în Bucuresti si cu competentă pe toată tara pentru problemele formării poporului român se izbește însă de opunerea si de susceptibilitatea Clujenilor. Forurile superioare au acum în cercetare această gingasă problemă.

Vă rog să luati în cunoștintă acest stadiu în care se găsesc problemele cercetării formării poporului român.

20 martie 1964

Prof. Gh Cantacuzino

\section{REZULTATELE UNEI CONVORBIRI CU PROFESORUL VASILE MACIU CE A AVUT LOC ÍN ZIUA DE 23 MARTIE 1964. PĂRERI ASUPRA ETNICITĂTII CULTURII DRIDU}

\section{Convorbire cu (profesorul) V(asile) Maciu la 23 III 1964}

1. Discutat asupra lucrărilor arheologice din anii 1957-1963. Discutia s-a orientat repede asupra lucrării despre săpăturile de la Dridu.

2. Lucrarea tov. (Eugenia) Zaharia despre Dridu a fost citită de C(onstantin) Daicoviciu şi de $V$ (asile) Maciu. C. Daicoviciu a discutat despre ea cu V. Maciu şi a întocmit şi un referat despre ea. El se opune categoric la editarea acestei lucrări, dând argumentele următoare:

1. Muntenia nu a fost niciodată colonizată de romani. Nu s-a stabilit aici o masă de populatie romană, nici nu a fost astfel romanizată.

2. Pe bază de cercetări arheologice a fost descoperită cultura din sec. X numită Dridu. Discutia sa fãcut asupra caracterului acestei culturi. Se pot face două ipoteze:

a. Cultura Dridu ar fi romanică în confinut material şi ar apartine populatiei străromâne.

În acest caz se creează o nedumerire - Muntenia nu a avut o bază de romanitate fiindcă nu a fost colonizată. Deci nu a existat aci o populație băştinaşă romană sau dacică romanizată.

Dacă admitem că cultura Dridu este romanică şi a străromânilor nu putem explica aparifia ei decât prin emigrarea în sec. X la nord de Dunăre a populatiei romanice locuind la sud de Dunăre.

Aceasta este o posibilitate.

Însă această părere este „sudistă”, se situează pe aceeaşi bază de argumentare ca şi Rössler şi Gy. Györffy. Dacă tov. I. Nestor şi Eugenia Zaharia o susfin ei sunt ,,sudişti".

b. În aceeaşi linie de gândire este atribuirea unui rol decisiv Imperiului Bizantin în formarea poporului român, adică în sec. X sub impărafii Tzimiskes şi Vasile II Bulgarohtonul. Nu se poate explica formarea poporului român prin cauze externe, prin rolul Imperiului Bizantin. Şi această idee este apropiată de pozitia sudiş̧ilor.

c. Cultura Dridu a fost găsită şi în aşezări din Moldova (nordul Moldovei). Dacă se admite ca fiind romanică, ne putem întreba care ar fi fost baza de romanitate existentă în Moldova pentru a crea aci această cultură materială.

Moldova nu a fost nici stăpânită, nici colonizată de romani. A fost locuită de dacii liberi, apoi de goti şi de alte popoare migratoare. Cum se poate explica aparitia culturii Dridu având caracter romanic în Moldova în sec. X când nu a existat nici o populatie romană sau romanizată.

După V. Maciu elementele româneşti au venit în Moldova apoi, în sec. XIV, din Ardeal. 
d. Aceste argumente indică mai de grabă că cultura Dridu a fost o cultură mixtă, formată din aportul mai multor popoare dintre care şi elemente romanice. Cultura aceasta a fost prelucrată de mai multe popoare - daci, slavi, protobulgari.

e. Cultura Dridu, care a apărut și la sud de Dunăre este rezultatul contopirii mai multor influențe şi culturi de la mai multe popoare.

f. Prezenta culturii Dridu nu dovedeşte prezenła unei populatii străromâne.

g. Muntenia a fost locuită de numeroase triburi slave, care existau încă în sec. X şi vorbeau limba slavă. A existat o clasă dominantă slavă în toate regiunile României, ea a vorbit limba slavă până foarte târziu (după V. Maciu o mai vorbea şi în sec. XIII-XIV). După un cercetător sovietic clasa dominantă din România a vorbit limba slavă până în sec. XVI.

Numai astfel se poate explica introducerea timpurie a limbii slave în biserică şi ca limbă oficială.

Menumorut, Glad sunt nume slave. Cele mai multe nume ale boierilor cumani sunt slave. Boierimea română a fost în majoritate de origine slavă.

h. Cum explică tov. I. Nestor introducerea limbii slave în stat şi biserică la români dacă crede că cultura Dridu, din sec. $X$, este romanică şi că populatia ei vorbea limba străromână (romanica). Normal ar fi fost ca limba de stat și de biserică să fie cea latină sau străromânească.

i. Contopirea slavilor şi a populatiilor barbare s-a făcut mai târziu, intre sec. X şi XIV şi nu era terminată în sec. XIV.

j. Este deci important de a se cerceta perioada de la sec. $X-X I V$, căci în această perioadă $s-a$ format poporul român.

\section{NOTĂ INFORMATIVĂ REFERITOARE LA CONSTITUIREA UNOR COLECTIVE PRIVIND DIFERITE ASPECTE ALE FORMĂRII LIMBII ȘI POPORULUI ROMÂN ${ }^{3}$}

\section{Notă informativă}

Pentru continuarea cercetărilor arheologice privind formarea poporului român şi pentru valorificarea şi publicarea rezultatelor deja obtinute prin săpăturile efectuate şi prin alte cercetări istorice din trecut, credem că este neapărat necesar de a se creia următoarele două colective de lucru:

1. Un colectiv, compus din cercetătorii care au executat săpături în ultimii opt ani în problemele formării poporului român sub conducerea prof. I. Nestor. Acest colectiv urmează să continue lucrările arheologice incepute şi altele în perspectivă, să valorifice rezultatele lor pe baza unui plan de lucru precis şi să pregătească publicarea lor. Este necesar ca acest colectiv să fie dotat cu mijloacele materiale corespunzătoare.

2. Un colectiv, compus din istorici, care sub conducerea acad. Andrei Otetea, să continue în problemele formării poporului român cercetările pe baza izvoarelor scrise, întocmind un plan de lucru precis şi pregătind lucrări referitoare la unele aspecte şi obiective incă necercetate. Acestui colectiv urmează să $i$ se asigure de asemeni mijloacele materiale cuvenite.

3. Din ambele colective considerăm că este neapărat necesar să facă parte prof. Vasile Maciu, membru corespondent al Academiei R.P.R.

\footnotetext{
${ }^{3}$ Nu reiese cui a fost adresată şi nici data redactării ei. Oricum, ea datează din anul 1964.
} 
10. MEMORIU PREGĂTIT PENTRU VASILE DINU, ÎN 1965, DAR NEÎNAINTAT. REFERITOR LA NECESITATEA PUBLICẢRII UNOR MONOGRAFII ARHEOLOGICE.

\author{
Tov. Vasile Dinu \\ Vicepreşedintele Comitetului Nafional pentru Cultură şi Artă
}

Consider necesar a aduce la cunoştinţă următoarea situațiune în legătură cu cercetările referitoare la formarea poporului român :

In ultimul deceniu (1955-1965) s-au efectuat cu fondurile Academiei R.P.R. lucrări de prospecţii şi de săpături arheologice in Muntenia de nord-est, în zona din jurul Bucureştilor, în Transilvania centrală şi de sud-est, cât şi în Moldova. Aceste cercetări executate de un grup de arheologi sub indrumarea dată de Prof. Ion Nestor, au avut ca obiectiv de a descoperi şi de a cunoaşte culturile materiale ale populatiilor, care au locuit la nord de Dunăre, în tinuturile intra şi extra carpatice în perioada de la sec. IV e.n. până în sec. XIV e.n. şi de a completa astfel prin documente arheologice lipsurile din izvoare istorice scrise.

Prin aceste cercetări s-au descoperit în ultimul deceniu o serie de culturi materiale care au acoperit în parte intervalul dintre sec. IV și sec. XI e.n. si au făcut să crească enorm cunoștinłele noastre istorice.

Culturile materiale descoperite sunt: cultura Bratei descoperită pe teritoriul acestei comune, raion Mediaş (Transilvania), cultura Ciurel-Ipoteşti-Cândeşti cu cele două aspecte deosebite numite Ciurel şi Ipoteşti-Cândeşti. Această cultură ocupa Muntenia de vest, centrală şi de est în sec. VI-VII e.n.

Osebit a fost descoperită cultura Dridu, după numele acestei comune din raionul Urziceni, unde sa găsit o aşezare datând din sec. X-XI e.n.

Culturile materiale mentionate aparţin în sec. V şi VI e.n. populaţiei băştinaşe romanizate, care a locuit în teritoriul de la nord de Dunăre înainte de venirea triburilor slave.

Faza a IV-a din cultura Cândeşti, ultima fază din cultura Ciurel şi cultura Dridu cuprind un fond băştinaş romano-bizantin peste care au fost altoite elemente imprumutate slavilor. Aceste culturi materiale au fost create in timpul simbiozei româno-slave din sec.VII e.n. până în sec. IX-XI e.n. Ele sunt primele forme ale culturii materiale proto-române.

Mai mentionăm că prin excursii arheologice efectuate în Moldova de sofii Zaharia au fost identificate un mare număr de aşezări încadrate cronologic între sec. IV şi V e.n.

În sfârşit, alte aşezări româno-slave datând din sec. VII e.n. au fost găsite în Transilvania de est.

Ori, in urma acestor lucrări au fost redactate o serie de importante monografii și studii arheologice privind diversele culturi si cuprinzând rezultatele săpăturilor efectuate si monumentelor descoperite.

In situatia actuală aceste valoroase lucrări monografice care au o importantă esentială pentru problemele formării poporului român, nu pot fi editate, deși sunt redactate, din lipsă de spatiu poligrafic si de mijloace materiale.

Aducând la cunoştinta Comitetului Nafional pentru Cultură şi Artă această gravă situatie, care împiedică valorificarea în bune conditii a cercetărilor privitoare la formarea poporului român, solicităm să se ia în considerare posibilitatea de a se edita aceste monografii si studii arheologice cu sprijinul si cu mijloacele materiale ale acestui Comitet National, tinându-se seama de faptul că unele din aceste cercetări au fost făcute cu fondurile unor muzee regionale sau raionale, iar altele cu fondurile date de Academia R.P.R. singură sau în asociatie cu unele muzee.

Considerăm că această importantă problemă este just să fie examinată in mod atent de către Comitetul National pentru Cultură și Artă.

LUPTĂM PENTRU PACE,

Prof. G. Cantacuzino 
Către:

\author{
Comitetul Central al P.M.R. \\ Secfia Ştiinţă şi Cultură
}

- in atentia tov. Ilie Diculescu -

Consider necesar a aduce la cunoștință unele situaţii care constituie oprelişsti serioase în cercetările arheologice referitoare la o problemă esentială: aceea a formării ş̧i continuitătii poporului român.

În ultimul deceniu (1955-1965) s-au efectuat cu fondurile Academiei R.P.R. lucrări de prospectii şi de săpături arheologice în Muntenia de nord-est, în zona din jurul Bucureștilor, în Transilvania centrală şi de sud-est cât şi în Moldova. Aceste cercetări executate de un grup de arheologi sub indrumarea dată de Prof. Ion Nestor, au avut ca obiectiv de a descoperi si de a cunoaște culturile materiale ale populatiilor, care au locuit la nord de Dunăre. în tinuturile intra si extra carpatice în perioada de la sec. IV e.n. până în sec. XIV e.n. şi de a completa astfel prin documente arheologice lipsurile din izvoare istorice scrise.

Rezultatele obfinute prin lucrările din ultimul deceniu sunt importante şi cuprind următoarele :

1. Descoperirea culturii Bratei. Prin săpăturile arheologice conduse de prof. I. Nestor pe teritoriul comunei Bratei, raion Mediaş (Transilvania), s-a găsit:

a. o necropolă şi o aşezare care prin ceramica sa lucrată la roată, asemănătoare cu aceea a cetătilor romano-bizantine de pe malul Dunării şi prin celelalte materiale arheologice a fost datată de la sfârşitul sec. IV e.n. până în prima jumătate a sec. Ve.n.

b. $o$ aşezare atribuită celei de a doua jumătăłi a sec. V e.n. şi primei jumătăti a sec. VI e.n. prin analogie cu materialele bine datate prin monete descoperite în oraşe şi cetăti de pe malul Dunării.

2. Descoperirea culturii Ciurel-Ipotești-Cândești având cele două aspecte:

a. Aspectul Ciurel. În jurul Bucureştilor, pe dealul Ciurel, în suburbia Militari (Câmpul Boja), la Străulești, la Băneasa, la Cătelu Nou, la Fundeni, la Cernica s-au descoperit o serie de alte așezări având o cultură materială numită Ciurel, datată din sec. VI-VII e.n.

b. Aspectul Ipotești-Cândești. Prin săpăturile executate la Ipoteşti lângă Olt, la Târgşor lângă Ploieşti, la Cândeşti, Budureasca, Bozieni, Ceptura (reg. Ploieşti) au ieșit la iveală aşezări având cultura materială numită Ipoteşti-Cândeşti datată prin materialele găsite de asemeni din sec. VI-VII e.n.

Intre aspectele culturale Ciurel şi Ipoteşti-Cândeşti, care sunt relativ sincronice, există unele asemănări, dar şi deosebiri.

3. Descoperirea culturii Dridu. Prin săpăturile efectuate de Prof. I. Nestor pe teritoriul comunei Dridu, lângă Urziceni, s-a găsit o aşezare datată din sec. $X-X I$ e.n. având cultura materială numită Dridu, constatată şi în alte numeroase aşezări din Tara Românească, din Moldova şi din Transilvania, având inceputurile sale în sec. IX şi continuând până în sec. XI e.n.

Culturile materiale găsite la Bratei, Ciurel, Ipoteşti-Cândeşti (fazele I-II) apartin populatiei băştinașe romanizate, sunt anterioare venirii triburilor slave şi au avut strânse legături cu cultura romană târzie şi bizantină. Faza IV din cultura Cândeşti, ultima fază din cultura Ciurel şi cultura Dridu cuprind un fond băștinas romano-bizantin peste care au fost altoite elemente imprumutate slave. Aceste culturi au fost create in timpul simbiozei romano-slave in sec. VII e.n. şi IX-XII e.n. Ele sunt primele forme ale culturii materiale proto-române.

Se constată prin urmare că săpăturile amintite au adus descoperirea mai multor culturi materiale, care au acoperit in parte intervalele dintre sec. IV și sec. XI e.n. Prin aceste lucrări cunosstintele istorice au crescut enorm. Mai rămân să fie descoperite şi precizate culturile materiale din sec. VIII-IX e.n. şi din sec. XII-XIII e.n.

Deşi au fost obtinute aceste insemnate rezultate in ultimii zece ani, cercetările arheologice privind problemele formării şi continuitătii poporului român sunt acum stânjenite printr-o serie de lipsuri care impiedică executarea și dezvoltarea lor pe baze stiintifice:

\footnotetext{
${ }^{4}$ Necesitatea creării unui organ de coordonare și conducere a problemelor formării limbii și poporului român, organism ce să fie sub conducerea profesorului Ion Nestor.
} 
a. lipsa unui colectiv care să se ocupe de a cerceta în mod unitar si sistematic problemele formării poporului român, ceea ce constituie un viciu fundamental al acestor cercetări.

Într-adevăr nu este admisibil, nici just ca cercetarea problemelor vaste şi complexe, pe care le pune formarea poporului român, să se efectueze în mod împrăstiat și disparat, pierzându-se un timp prefios şi consumându-se forje şi mijloace materiale, care ar putea da rezultate mult mai mari, dacă ar exista o coordonare organizată a lor.

b. lucrările arheologice privind formarea poporului român se fac acum fără să existe un plan de ansamblu al lor, deci în mod neunitar şi cu mijloace dispersate de către unii arheologi lucrând la Institutul de Arheologie şi la filialele Academiei de la Cluj şi Iaşi, ceea ce constituie o gravă eroare.

c. Pentru rezolvarea problemelor variate privind formarea poporului român este absolut necesar ca cercetările să fie executate după un plan general întocmit pe întreaga ţară în urma unor analize şi discuţii la un înalt nivel știintific. Acest plan urmează să cuprindă:

I. zonele în care trebuie să se efectueze prospectii arheologice prealabile pentru a se stabili locurile in care s-au păstrat urme din trecut.

II. locurile care trebuie cercetate prin săpături şi care cuprind urme.

III. problemele principale care trebuie urmărite prin săpături.

$I V$. rezultatele cercetărilor deja executate care trebuie editate.

Considerăm că in vederea acestei activităti complexe este absolut necesar de a se crea un organ de îndrumare si de coordonare. In acest scop, credem că se impune să se înfiinteze pe lângă Academie sau pe lângă Institutul de Arheologie un colectiv arheologic, care, sub conducerea tov. Prof. Ion Nestor să facă prospectii şi săpături în diverse regiuni din tară, să stabilească obiectivele pentru fiecare regiune şi să urmărească punctele mai sus arătate.

Având în vedere lipsurile amintite, care constituie o gravă piedică în dezvoltarea cercetărilor privind formarea poporului român, considerăm că este just şi urgent de a se crea un colectiv de cercetare arheologică, care sub îndrumarea tov. Prof. I. Nestor să coordoneze aceste lucrări şi să aibă la dispoziţie mijloacele materiale necesare pentru executarea lor şi publicarea rezultatelor.

LUPTĂM PENTRU PACE

iunie 1965

Prof. G. Cantacuzino

Conducătorul șantierului arheologic Cernica

al Academiei R.P.R. 
II. NOTE REFERITOARE LA ŞANTIERUL ARHEOLOGIC MĀNĀSTIREA PUTNA

Mănăstirea Putna, loc de veneraţie şi de profunde aduceri aminte pentru istoria și credinţa ortodoxă a naţiunii noastre, s-a bucurat, în toate vremurile, de $o$ atenţie deosebită din partea guvernanţilor şi implicit a istoricilor şi arheologilor români şi străini.

În ultimii ani ai deceniului şapte ai secolului XX Mănăstirea Putna a fost supusă unor ample lucrări de restaurare ce au implicat şi săpături arheologice. Pentru lămurirea diferitelor discuţii, nu puţine şi în contradictoriu, între istorici, arheologi și arhitecţi, s-au constituit comisii de evaluare. În cele ce urmează prezentăm mai întâi „Procesul verbal încheiat azi 20 octombrie 1970, la Putna, cu ocazia şedinţei de lucru a specialiştilor invitaţi pentru a discuta stadiul lucrărilor de cercetare şi restaurare a Complexului monumental Putna" (punctele 1 şi 2), iar apoi notele luate de către prof. Gheorghe Cantacuzino în ziua de 21 decembrie 1973, la comunicarea ţinută la Institutul de Arheologie din Bucureşti de către Gheorghe I. Cantacuzino și Alexandru Rădulescu - Ceramica de la Putna (punctul 3).

1. Proces verbal incheiat azi 20 octombrie 1970, la Putna, cu ocazia şedinfei de lucru a specialişstilor invitał̣i pentru a discuta stadiul lucrărilor de cercetare şi restaurare a Complexului monumental Putna.

Şedinfa a fost condusă de prof. arh(itect) Grigore Ionescu.

Au participat: Ion Moraru, vicepreședinte C(omitetul) de S(tat) pentru C(ultură) şi A(artă), arhitect Ştefan Bals, D(irecția) M(onumentelor) I(storice) - C.S.C.A., Radu Florescu, D(irectfia) M(uzeelor) - C.S.C.A., N(icolae) Puşcaşu, D.M.I. - C.S.C.A., arhitect Nicolae Diaconu, D.M.I. C.S.C.A., arhitect Ioana Grigorescu, D.M.I. - C.S.C.A., Lucian Roșu, redactia Muzee Monumente C.S.C.A., prof. Ion Nestor, Inst(itutul) de Arheologie (București), prof. Gh(eorghe) Cantacuzino, Inst(itutul) de Arheologie (București), Mircea Matei, Inst(itutul) de Arheologie (Bucureşti), Radu Popa, Inst(itutul) de Arheologie (Bucureşti), prof. Emil Läzärescu, Inst(itutul) de Ist(oria) Artei, Ştefan Olteanu, Institutul de Istorie (Bucureşti), prof. arh. Grigore lonescu, Inst(itutul) de Arhitectură, prof. Horia Teodoru, pensionar, arh. Virgil Bilciurescu, I.C.C.A.S., arhiereu (Irineu) Crăciunaş, Mitropolia Moldovei, ing. T. Mititelu, Departamentul Cultelor, ieromonah (Gherasim) Cocoşel, stareful Mănăstirii Putna, ieromonah Pimen Zainea, ghidul Colectiei Mânăstirii Putna.

Problemele aduse in discutie au fost :

11. Existenţa unui pridvor anterior secolului XVII, epocă din care datează monumentul actual

2\%. Marcarea fazei constructive anterioare secolului XVII (perioada lui Stefan cel Mare).

3/. Marcarea mormintelor din interior.

Au fäcut expuneri arh. Ioana Grigorescu şi arh. Nicolae Puşcaşu.

Din expunerea arhitectului Ioana Grigorescu s-au desprins următoarele :

- Existenta unei faze Ştefan cel Mare pentru pronaos, naos şi altar cu următoarele caractere: fundafie pe traverse, din zidärie, în şant, după un traseu de plan reproducând exact traseul din secolul XVII, dar mai îngust.

- Inexistenta unei faze anterioare secolului XVII la pridvor, unde:

- zidul de XVII se fese cu resturile pavajului datate de arheologul N. Puşcaşu in secolul XV.

- fundatia descoperită în exteriorul pridvorului, către vest, este separată printr-un şlit de fundație de secol XVII și este considerată ca o plombă târzie (sec. XIX).

- cele două pavaje din priduor se datează - cel mai vechi, cu dalele de piatră, din secolul XVII, cel de-al doilea pe lut bătut din secolul XIX (Iacob Putneanu).

- inmormântärile din pridvor, extrem de dese, și cu construcfii speciale (cavouri) sunt de datat în secolul XVII, considerând neconcludentă stratigrafia stabilită de N. Puşcaşu.

- zidul de fundafie de sub zidul de nord al pridvorului este, fie acelaşi cu cel din secolul XVII cu care filează, fie un zid de ranforsare al peretilor cavoului alăturat, contestând observatia lui $N$. Puşcaşu că ar constitui o fundatie anterioară net deosebită de fundafia din secol XVII. 
- a propus marcarea mormintelor din biserică, prin trasarea contururilor fiecărui mormânt, cu un fir de aramă incastrat într-un şlit.

- a propus marcarea fundaţiilor de secol XV printr-o diferentă de exceptie a pavajului.

Arheologul Nicolae Puşcaşu a arătat demonstrând cu planuri şi profile stratigrafía următoare:

- atât zidul de nord, cât şi cel de vest sunt anterioare refacerii din secolul XVII şi anume resturile lor sunt acoperite de stratul de incendiu din 1484 - in exterior - şi de pavajul din secol XV - in interiorunde stratul de incendiu nu poate fi identificat.

- cele două pavaje se datează astfel: cel cu dale de piatră in secolul XV, anterior lui 1484 și este străpuns de inmormântări care nu au putut fi datate precis nefiind cercetate; iar cel de al doilea se datează in secolul XVII, nivelul lui acoperind direct decroşul fundatiilor din secolul XVII.

- stabileşte o stratigrafie de depuneri diferită de aceea din exterior şi anume fără straturi de incendiu şi stratul de nivelare de după incendiu (1484) ceea ce devine concludent pentru datarea construirii pridvorului anterior secolului XVII.

- explică includerea resturilor de pavaj, unul din pridvor în fundatia de secol XVII prin incastrare a fundafiei XVII cu cea de XV pentru ranforsarea coltului.

- propune o marcare selectivă a mormintelor, marcarea integrală putând să producă confuzii.

- propune renuntarea la marcarea stâlpilor de colt din pronaos, unde săpăturile arheologice nu numai că n-au descoperit fundatiile lor, dar au descoperit guri de scurgere incompatibile cu prezenta stâlpilor.

Discutiile s-au purtat prin interventii în cursul expunerilor precum şi probleme si detalii la fata locului. Ele nu au avut drept scop verificarea expunerilor fiecărui participant, ci clarificarea observafilor si concluziilor celor doi cercetători în vederea stabilirii faptelor.

La discutii au intervenit: Virgil Bilciurescu, Ion Nestor, Ion Moraru, Radu Florescu, Grigore Ionescu, Mircea Matei, Radu Popa, Horia Teodoru, Ștefan Balş, arhiereu (Irineu) Crăciunaşs şi ieromonah (Gherasim) Cocoşel.

În cursul discufiilor pe săpătură s-a constituit o subcomisie din arh. Virgil Bilciurescu şi Radu Florescu, care au verificat la faţa locului şi in toate punctele posibile raporturile topografice şi stratigrafice dintre zidăriile din pridvor.

Din toate aceste discufii și verificări la fața locului au rezultat următoarele :

- există o fază anterioară reconstrucţiei din secolul XVII la pridvor, reprezentată prin cele două fundatii mai vechi din sud şi vest care se disting clar şi sunt partial acoperite de fundatiile din secolul XVII (vezi pct. 3 şi 4).

- datarea anterioară anului 1484 pentru pridvor nu este absolut certă, existând observatii stratigrafice pentru această datare, precum şi unele care o contrazic. În cursul discufiei nu s-a putut propune altă datare diferită de cea stabilită de Nicolae Puşcaşu.

Problema datării precise a pridvorului anterior secolului XVII rămâne încă deschisă, urmând să se rezolve prin adâncirea cercetărilor şi publicarea discufiilor.

În functie de aceste elemente urmează să se dateze şi cele două pavaje din pridvor.

Ca urmare a celor de mai sus se propun următoarele măsuri:

1) Marcarea in pavaj, ca şi în exterior, a resturilor primei faze, atât ale naoslui, pronaoslui şi altarului, cât şi a pridvorului. Se poate lua în considerare o marcare a resturilor pridvorului uşor diferită de aceia din restul bisericii.

2) Amenajarea de accese la fundafiile din prima fază în toate incăperile bisericii, inclusiv pridvorul, atât pentru vizitare, cât şi pentru verificările specialiştilor; se va examina şi posibilitatea realizării unui asemenea acces la mormântul lui Stefan cel Mare. Punctele de acces (puturi cu trepte de coborâre) vor fi stabilite, de comun acord, de către arhitecti şi arheologi, până cel târziu la 30 XI a.c.

3) Având in vedere numărul relativ mare de morminte, neidentificarea lor, precum si suprapunerea unora dintre acestea, să se renunte la marcarea în pavaj a mormintelor; prezentarea mormintelor, cu toate datele posibile, se va face prin intermediul unor planuri ce vor fi expuse atât in biserică, cât şi în muzeu.

O parte din cei prezenti (Mircea Matei, Radu Florescu, Lucian Roşu, Emil Lăzărescu, Nicolae Puşcaşu. Horia Teodoru) au susf̧inut necesitatea marcării, intr-un mod potrivit, a mormântului lui Ştefan cel Mare.

4) Continuarea cercetărilor pentru Complexul Putna şi finalizarea acestora, până in prima jumătate a anului 1971, de către un colectiv de arheologi sub egida Academiei de Știinte Sociale şi 
Politice - respectiv Institutul de Arheologie (din Bucureşti) - din care să facă parte şi arheologul Nicolae Puşcaşu.

Până la 30 noiembrie a.c. se vor elabora planul de cercetare, planul financiar şi componenţa colectivului, urmând ca imediat ce condifiile naturale vor permite să se înceapă cercetările.

5) $S$-a indicat ca pe baza celor stabilite să se accelereze lucrările la biserică, in aşa fel încât restaurarea să se termine în cursul anului 1971. În acest sens, se vor lua măsuri pentru astuparea imediată a tuturor sectiunilor arheologice in care cercetarea s-a incheiat și problemele au fost complet lämurite.

6) În termen de 30 zile de la terminarea cercetărilor Directia Monumentelor Istorice va prezenta un program de lucru cuprinzând termene precise pentru proiectarea şi execuția lucrărilor menite a pune in valoare intregul Complex Putna.

Comisia a apreciat în cel mai înalt grad săpătura exemplară a arheologului Niculae Puşcaşu, precum şi interesul pentru cercetare a arhitectilor Ioana Grigorescu şi Nicolae Diaconu.

Observatii asupra Procesului Verbal încheiat la 20 oct. 1970 la M-rea Putna.

1. Propun modificarea textului expunerii tov. arh. Ioana Grigorescu (pag. 2) după cum urmează:

Paragraful 1 - fundatie pe traverse de lemn in şant

In loc de - fundatie pe traverse de zidărie în şant.

Paragraful 7 - zidul de fundafie de sub zidul de nord al pridvorului este fie acelaşi cu cel din sec. XVII din pronaos, cu care filează ...

In loc de - zidul de fundafie de sub zidul de sud al pridvorului este, fie acelaşi cu cel din sec. XVII cu care filează ...

2. idem din expunerea tov. arh. Niculae Puşcaşu (pag. 3):

Paragraful 2 - atât zidul de nord

In loc de - atât zidul de sud.

Arh. Balş Ştefan

Sunt de acord cu propunerile de modificare propuse de Sttefan Bals, la care aşi mai adăoga, în legătură cu cele arătate la pag. 4, par. 2, că nu s-a discutat şi nici nu cred că ar fi nimerit să se amenajeze un puf cu trepte la mormântul lui Ştefan cel Mare. Să nu se uite că Ştefan şi-a aşezat piatra de mormânt cu inscriptia acolo unde este, fiind în viafă şi că deci mormântul în care urma să fie aşezat după moarte nu putea fi decât alături, cam acolo unde este. Aş mai adăoga de asemeni că ar fi util să se cerceteze toate mormintele din pridvor fapt care ar putea lămuri unele datări. Lucrul este cu atât mai natural cu cât mormintele sunt în săpătură deschisă.

Grigore Ionescu

Sunt şi eu de acord cu propunerea de a se cerceta mormintele din pridvor.

Ion Nestor, Gh. Cantacuzino

2. Gh. Cantacuzino - Notă privind discufiile avute la Mănăstirea Putna, octombrie 1970

\section{Problema marcării mormintelor.}

1) Gr. Ionescu arată că Putna a fost o necropolă princiară. Cere să se marcheze toate mormintele şi exclusiv ele, datând din sec. $X V$, eventual $X V I$.

2) Mircea Matei propune să se marcheze exclusiv mormintele membrilor familiei domnești. Osebit să se expună un plan al tuturor mormintelor din biserică.

3) În această biserică există mormântul lui Ştefan cel Mare, Mariei din Mangop, Mariei Voichiła, Maria mama Mariei Voichita.

4) Gr. Ionescu propune apoi să se marcheze numai mormintele domneşti care au conservate o lespede de piatră. 


\section{Problema zidului de vest a bisericii si a existentei pridvorului vechi.}

Arh. Grigorescu argumentează astfel: nu era posibil ca zidul de vest al bisericii să fie mai pufin gros decât celelalte ziduri ale bisericii.

Doamna Grigorescu sustine că fatada intrării bisericii lui Ştefan cel Mare este mult intrată, adică cu 1,20 m înăuntru. Atunci am avea un zid de vest gros ca şi la celelalte ziduri.

Dna Grigorescu încearcă existenfa unui contrafort care ar dovedi limita spre vest a bisericii.

Combate in cazul că ar fì oprit pe arheolog N. Puşcaşu de a executa cercetarea arheologică la pridvorul Putnei.

Au fost găsite 2 sisteme de fundatie pe tot conturul bisericii vechi, iar la (?) s-a găsit un singur sistem de fundatie a pridvorului.

$S$-au găsit pilofi de lemn sub fundatia pridvorului la mare adâncime, cu scopul de a opri o tasare deosebită a fundatiei. Au fost găsite canale longitudinale din care au rămas păstrate mulaje.

Dna Grigorescu susfine că aceasta a fost o pardoseală a fundafiei peste care a fost ridicată biserica lui Ştefan cel Mare.

Dna Grigorescu a recunoscut fundatia din sec XVII, însă $n u$ s-a iscălit in observafiile stratigrafice.

După N. Puşcaşu există o fundatie din sec. XV, apoi o lătire, apoi o pardoseală.

După Dna Grigorescu pardoseala pridvorului datează din sec. XVII-lea.

In vara 1970 au apărut două trepte de zidărie late de 0,80-0,97 m.

După N. Puşcaşu prima treaptă de zidărie apartine pridvorului din sec. XV.

După arh. Grigorescu prima treaptă este o corectare a constructiei pridvorului din sec. XVII-lea. Pridvorul are două niveluri - unul la (?) şi altul cu 0,35-0,60 m mai sus.

A fost găsit un pasaj la $-1,04 \mathrm{~m}$ in curte, in fata pridvorului. După arh. Grigorescu acest pavaj este din secolul XVII deoarece după ce a fost demolat contrafortul din sec. XVII există pietre indicând un pavaj, care este pe nivelul din sec XVII.

Alt pavaj găsit la $-1,64 m$ prevăzut cu o monetă din sec. XV şi ar data după cel din sec. $X V$. Este combătut de Dna Grigorescu şi atribuit sec. XVII.

Constructorii din sec. XVIII după arh. Grigorescu au plombat pardoseala în urma prăbuşirii unui contrafort şi au făcut un şant de interventie în sec. XVIII. Deci pardoseala pomenită este din sec. XVII, fiind anterioară.

Nestor întreabă - dacă însă pardoseală e din sec. XV atunci şanţul executat e din sec. XVII.

După arh. Grigorescu nu există o fundatie de pridvor din sec. $X V$, ci doar o treaptă şi nici o pardoseală din sec. $X V$.

Arată că N. Puşcaşu și-a schimbat in 1970 observatiile făcute în trecut; atunci inseamnă că observatiile arheologice nu au o bază știintifică.

Arh. Grigorescu admite existenta unui singur pridvor, acel din sec. XVII. După ea biserica din Putna a avut la toate zidurile o grosime de $2,20 \mathrm{~m}$ și nu este posibil numai ca zidul de vest a bisericii să fi avut o grosime de 0,70-0,75 m. Trebuie să fi avut 2,20 m.

M. Matei intreabă de ce tocmai spatiul situat în dreptul intrării în biserică nu avea pridvor, el trebuia să fie la acelaşi nivel ca și restul curtii.

$M$. Matei și $R$. Florescu intreabă de ce acest spatiu avea în sec. $X V$ un alt nivel decât restul curtii şi arh. Grigorescu răspunde că s-au scos de aici straturi de pământ.

Arh. Grigorescu declară că are o experientă de 30 ani şi că ea a lucrat planul de restaurare. Arheologii și-au schimbat părerile de mai multe ori. Pretinsul pridvor din sec. $X V$ nu se alienează pe linia zidurilor din sec. $X V$. atunci.

III. În august 1970 a venit un grup de arheologi să vadă rezultatele săpăturilor obfinute până

IV. N. Puşcaşu a găsit prin săpături urmele unei biserici anterioare sec. XVII şi s-a stabilit planul ei, grosimea zidurilor între 2,12-2,20 m. Era plină de morminte.

Toti cercetătorii şi arhitectii au admis că biserica actuală este acea din sec. XVII.

În 1969 s-au găsit elemente refolosite şi provenind din prima biserică.

Biserica cea nouă din sec. XVII a pornit de la pardoseala din prima biserică care conținea vechile morminte.

Biserica cea nouă a fost retrasă cu circa $0,70-0,90 \mathrm{~m}$, astfel retragerea a fost de $0,80 \mathrm{~m}$, chiar la zidul de vest al bisericii din sec. XVII.

A fost găsită o placă de mortar de 0,003 $\mathrm{m}$ datând din sec. XVII, peste placa de mortar a bisericii din sec. XV. Sub aceasta exista o treaptă de acces la acest nivel. 
Invocă planul bisericii de la Dolheștii Vechi unde pridvorul vechi era mai lat în interior decât pronaosul bisericii din sec. $X V$.

Încă din 1969 N. Puşcaşu a stabilit că în faţa intrării bisericii vechi din sec. XV a existat un spatiu pardosit şi prevăzu cu morminte.

În 1969 nu se găsise încă zidul de sud al fundatiei din sec. XV.

Constructorul din sec. $X V$ a stabilit fundatia bisericii vechi şi a pridvorului pe un strat de pietriș cu grosime inegală, ceea ce a dus la crăpături în această fundaţie. De aceea a fost dărâmată vechea biserică.

Există un mormânt exterior din cărămizi lângă zidul nordic al bisericii vechi. Ar putea să fie mormântul egumenului mitropolit Teoctist.

Incendiul din 1474 nu a lăsat urme în spatiul pridvorului.

Tehnica folosirii de piloti sub fundatie a variat, căci s-au folosit și grile de lemn așezate orizontal pe stratul de pietriş.

N. Puşcaşu evocă un text din perioada lui lacob Putneanu, dar preşedintele Macovei exprimă deja o nedumerire. Acest text foloseşte termenul de "tribut" (?) fără să arate dacă era mic sau mare.

Macovei invocă şi un pasagiu a lui Neculce.

Ştefan Balș întreabă - mormintele din prituor datează oare din sec. $X V$.

Răspunsul lui Puscașu - s-a găsit ceramică fragmentară din sec. XV lângă morminte.

Stefan Balş intreabă - de ce s-au păstrat zidurile vechi din XV în gropnifa bisericii şi de ce nu sau păstrat fundafiile bisericii din sec. $X V$.

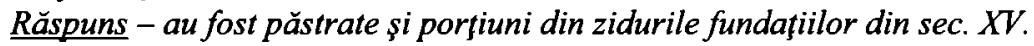

Mircea Matei - in pridvor există două faze, adică morminte vechi din sec. $X V$, apoi un strat de pământ de nivelare, şi apoi alte morminte, ulterioare, din sec. XVII. Sunt două niveluri cu două rânduri de morminte. Pământ adus prin nivelare căpăcuieşte pardoseala din sec. XV din primul pridvor şi el nu poate să fi fost adus mai târziu.

Arh. Grigorescu - tov. N. Pușcaşu si-a schimbat uneori părerile.

Emil Lăzărescu şi Gh. Cantacuzino - un arheolog care descoperă elemente în plus are dreptul de a-şi modifica părerea anterioară, această atitudine este spre onoarea lui.

Fundatiile pridvorului primei biserici sunt situate pe pietriş, cele din sec. XVII pe piloti aşezati în lat, la o diferenţă de nivel de $0,30 \mathrm{~m}$.

Pridvorul vechi a fost adăogat sub Ștefan cel Mare după zidirea primei biserici în 1460/1471, însă înainte de incendiul din 1484, deci tot în vremea lui Stefan cel Mare.

În a doua biserică din sec. XVII s-au făcut numai 7 înmormântări din lipsă de spafiu, formând două categorii de morminte. Avem deci 2 niveluri de călcare, 2 pridvoare suprapuse, 2 rânduri de înmormântări. Pardoseala din gropniţa din sec. XVII corespunde cu pardoseala din pridvorul din sec. XVII.

Şanţul de fundatie din sec. XVII urmăreşte mereu traseul zidurilor bisericii din sec. XV.

$S$-a pus întrebarea - pardoseala a doua cărui nivel din pronaosul bisericii i-ar corespunde. Răspuns - nu există.

Radu Florescu - există indicii că s-a procedat la o răzuire în curtea bisericii ?

Răspuns - există o zidărie adosată perfect zidului din sec. al XVII-lea al bisericii.

După N. Puşcaşu este încadrată în fundatia pridvorului din sec. al XV-lea.

Mircea Matei a întrebat pe arh. Grigorescu cum explică că pardoseala primă din pridvor dacă atribuim sec. al XVII-lea se află la un al nivel decât pardoseala primă din pronaos? Trebuie să admitem intre naos și pronaos existenfa unei trepte? 
3) Note luate de către profesorul Gh. Cantacuzino, în ziua de 21 decembrie 1973, la comunicarea tinută la Institutul de Arheologie din București de către Gheorghe I. Cantacuzino şi Alexandru Rădulescu - Ceramica de la Putna.

Ceramica a fost descoperită în exteriorul incintei, pe laturile de est și vest.

Materialul este databil în sec. $X V-X V I$ - boluri, străchini şi farfurii. Farfuriile fiind mai rare. Câteva ulcioare şi pahare. Predomină străchinile smălţuite - verde, roşu şi galben.

Decorul cu angobă aplicată.

Vase cu ornamentafie cu grafitti.

Lipsesc unele motive de caracter oriental. Provine de pe coasta de nord a Mării Negre, ea deosebindu-se de aceea din Moldova.

Nu se poate şti, din lipsă de săpături, dacă ceramica de tip Putna era răspândită şi în alte mănăstiri din Moldova.

Ceramica de la Putna era folosită de monahi şi de clasa nobiliară (boierească).

Cea din sec. XVI este posterioară zidirii incintei.

Pe 10 cioburi apare numele unui monah italian. S-ar putea ca cel pufin o parte din această ceramică să fi fost confecţionată de acest monah italian.

Săpăturile trebuie extinse în afara mănăstirii.

Trebuie avut în consideratie că unele forme vechi s-ar putea să fie mentinute în unele locuri până târziu.

63 de cioburi smăltuite cu vernil şi 4 cioburi fãră smalt cuprind nume ale fabricantilor vasului, neamul şi data, şi călugărul pentru care a fost creat.

Un vas are data de 1486 și numele Stefan.

Unele cioburi se referă la Mănăstirea Cotnari.

Un alt fragment este din anul 1430 sau 1435.

Se mai mentionează ca meşteri Eugenie, şi câteva nume cărora le era destinat vasul.

Câteva cioburi contin ornamente armeneşti.

Ceramica smăltuită se dezvoltă la Putna în a doua jumătate a sec. XV şi se continuă în sec. XVI. Era confectionată de meşteri imigrați. Era utilizată pentru nevoile mănăstirii.

$S$-au găsit farfurii cu fond alb şi decor. Exteriorul este angobat Au influente orientale şi este de import.

Ceramica nesmălţuită - vase cu picior îngust servind la păstrarea de alimente. Căni - lucrate la roata rapidă.

Problemele ceramicii nezmălłuite de la Putna nu sunt rezolvate. Ipotetic se pune întrebarea dacă aceste vase nu sunt anterioare mănăstirii, datând din sec. XIII-XIV.

Intrebări:

- S-au găsit cuvinte româneşti? Care sunt?

Răspuns - Strachină smălţuită.

La Cetatea de Scaun (Suceava) proporţia este mai mare de ceramică nesmăltuită față de cea

La Mănăstirea Galata există un vas mare care seamănă cu vasele de la Putna.

Corina Nicolescu aminteşte că la Cetatea din Suceava s-a găsit un singur fragment şi la Hârlău un alt fragment inrudit cu ceramica de la Putna.

Ceramica nesmălıuită era cea de uz intern folosită de călugări.

Petre Diaconu cere repetarea datelor de pe ceramică -1535, 1556, 1577.

După părerea lui Al. Rădulescu şi Gh. I. Cantacuzino ceramica zisă de lux era confectionată nu pentru piată ci pentru necesitătile întregi comunităti de la Putna.

Ion Nestor arată că ceramica smăltuită de la Putna putea să fie folosită pentru invitatii de marcă, de pildă primirea domnitorului și familiei sale, solilor străini.

Deci această ceramică are precis caracterul de ceramică de lux, specială, nefolosită zilnic.

Mircea Matei susfine că Mănăstirea Putna în sec. XV-XVI a avut un număr mic de călugări.

\footnotetext{
${ }^{5}$ Respectiva comunicare a fost apoi publicată în SCIV 25, 1974, 4, 527-544.
} 
După Corina Nicolescu în sec. XV la Moldovita erau 15 călugări. Slujitorii mănăstirii erau situafi departe de mănăstire, la $150-200 \mathrm{~m}$.

\section{Discufii:}

Petre Diaconu arată utilitatea comunicării, clasificarea ceramicii. Putna are o pozifie unică prin ceramica ei. Problema cea mai importantă este drumul pe care a venit -de-a lungul coastei Prutului. Meşterii au fost un număr redus de călugări olari-s-au găsit cinci nume.

La Putna această ceramică smălfuită poate fi considerată ca uzuală. Chiar din sec. XI ceramica bizantină smălfuită a circulat în masă şi a devenit uzuală.

Mircea Matei - Mănăstirea Putna din sec. XV şi XVI se diferentiază net prin valoarea ceramicii produse, în timp ce în sec. XVI ceramica orășenească decade - la Iaşi, la Vaslui, la Suceava -mai ales în a doua jumătate a sec. XVI. La Putna s-a afirmat un centru meşteşugăresc unicat a cărei productie nu se regăseşte la Suceava, Iaşi sau Piatra Neamt.

Apare puterea culturală a influentei bizantine venite de la est şi sud-est în Moldova. Moldova însă nu cunoaşte o influentă bizantină în oraşe şi la sate in sec. $X V-X V I$. Trebuie să se cerceteze raza de circulatie a ceramicii de la Putna.

Mircea Matei nu exclude circulafia acestei ceramici într-o anumită zonă din jurul Putnei, deci ea nu era exclusiv rezervată nevoilor mănăstireşti.

Termenul de ceramică de lux pentru cea smălfuită de la Putna nu trebuie considerat ca o ceramică de lux.

Corina Nicolescu - în muzeul de la Putna există fragmente ceramice decorate cu palmete. Existăo serie de motive orientale introduse, care nu aparțin ceramicii bizantine. Ceramica smălfuită care are inscriptii trebuie considerată de lux.

Corina Nicolescu contestă făurirea vaselor smăltuite cu inscripţii slave că ar fi fost neapărat create de meşteri călugări.

Ion Nestor - a) nu s-a prezentat o cronologie precisă a evolutiei acestei ceramici de la Putna.

b) Trebuie cercetat mai precis raportul cronologic dintre ceramica de uz obişnuit cu acea a ceramicii smălțite.

c) Există la Putna o formă de vas şi de decor din sec. XIII. Această formă trebuie urmărită şi explicată. Ar însemna că această formă a dăinuit până în sec. XV.

Maria Comşa - smalțul nu este colorat şi este compus din substanțe care-i dau o anumită culoare. Admite că ceramica smăltuită de la Putna putea să fie făcută de călugări.

\section{George TROHANI}

Muzeul Naţional de Istorie a României

Secția Arheologie

Calea Victoriei 12, 030026, Bucureşti.

gtrohani@yahoo.com 